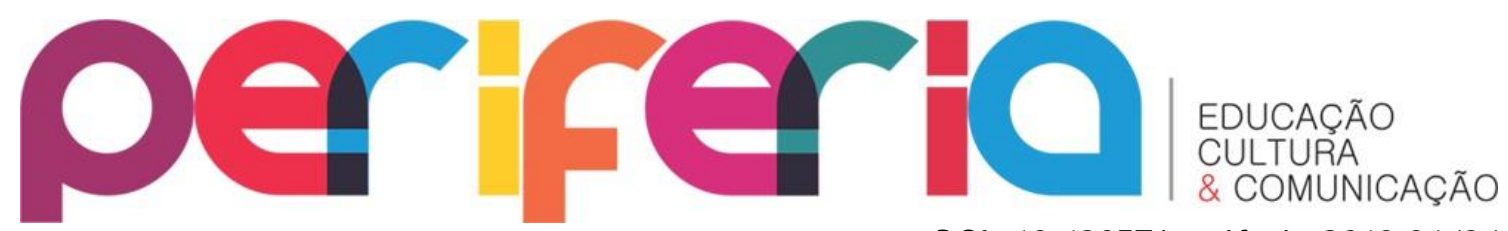

DOI: $10.12957 /$ periferia.2019.36434

\title{
ENSINO DE GRAMÁTICA: ANÁLISE DAS RELAÇÕES LÓGICO- SEMÂNTICAS DA CONJUNÇÃO EM MEMES
}

\author{
Ariana da Rosa Silva ${ }^{1}$ \\ Universidade Federal Fluminense - UFF
}

\section{Resumo}

Esta pesquisa está filiada aos procedimentos teórico-analíticos da Semiolinguística, com base em estudos de Charaudeau (1992), uma vez que essa proposta permite uma perspectiva mais ampla de análise do ensino de língua, o que possibilita trabalhar as relações lógicas em seus múltiplos aspectos semânticos. O objetivo deste estudo é analisar as relações lógico-semânticas das conjunções, especialmente, da conjunção "e" em textos do gênero textual meme. Assim, serão observados os sentidos que vão além dos propostos pela Gramática tradicional ensinada nas escolas, considerando que o ensino da língua pode ser muito mais efetivo se considerada em seus diferentes contextos e usos. Será, brevemente, desenvolvido um estudo sobre o gênero textual meme, observando sua origem e características próprias. Em seguida, serão abordados alguns conceitos da teoria Semiolinguística e, por fim, uma análise das operações lógicas, de acordo com o que Charaudeau (1992) propõe em sua Gramática do Sentido e da Expressão. A principal conclusão obtida nesse estudo, foi que uma conjunção, ou outra classe gramatical, não pode ser descrita e limitada a um único sentido, como tem sido feito pelas gramáticas tradicionais e utilizado pelas escolas de educação básica do Brasil. Isso porque, a partir do uso, podem ocorrer diversos efeitos contextuais para o mesmo elemento linguístico.

Palavras-chave: ensino; gramática; sentido; conjunção; meme

\footnotetext{
1 Doutoranda do Programa de Estudos de Linguagem na Universidade Federal Fluminense, sob orientação da Profa. Dra. Bethania Mariani. Mestra em Estudos de Linguagem pela Universidade Federal Fluminense. Possui graduação em LETRAS (Português/Literatura) pela Universidade Estácio de Sá (2008) e especialização em Leitura e Produção Textual pela mesma Universidade (2011). arianarosa86@gmail.com
} 


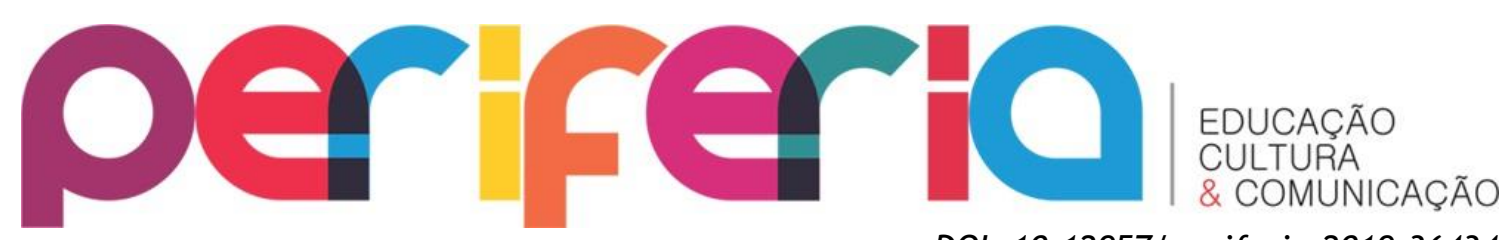

DOI: 10.12957/periferia.2019.36434

TEACHING OF GRAMMAR: ANALYSIS OF LOGICAL-SEMANTIC RELATIONS OF MEMES

\begin{abstract}
This research is related to the theoretical-analytical procedures of Semiolinguistic, based on studies by Charaudeau (1992), since this proposal allows a broader perspective of language teaching analysis, which makes it possible to work the logical relations in its multiple aspects semantics. The purpose of this study is to analyze the logical-semantic relations of conjunctions, especially of the conjunction "and" in texts of the textual genre meme. Thus, we will observe the meanings that go beyond those proposed by the traditional Grammar taught in schools, considering that language teaching can be much more effective if considered in its different contexts and uses. A study on the textual genre meme will be developed briefly, observing its origin and its own characteristics. Then, some concepts of the Semiolinguistic theory will be approached and, finally, an analysis of the logical operations, according to what Charaudeau (1992) proposes in his Grammar of Sense and Expression. The main conclusion obtained in this study was that a conjunction, or another grammatical class, can ' $t$ be described and limited to a single sense, as has been done by traditional grammars and used by Brazilian primary schools. This is because, from the use, several contextual effects can occur for the same linguistic element.
\end{abstract}

Keywords: teaching; grammar; sense; conjunction; meme 


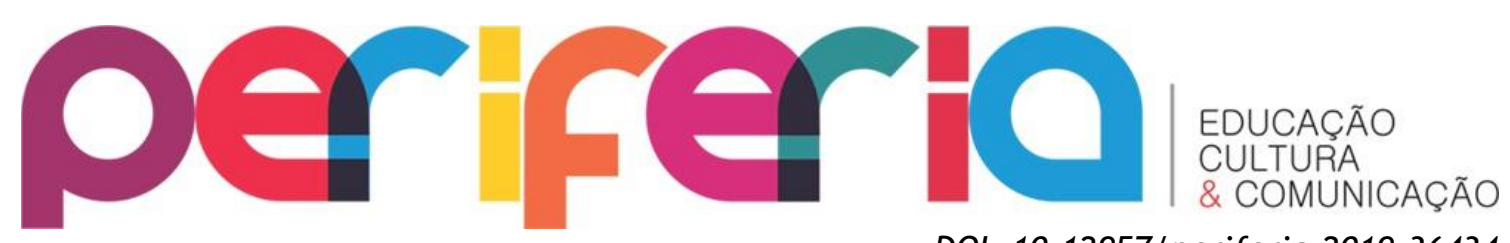

DOI: $10.12957 /$ periferia.2019.36434

\section{ENSEÑANZA DE GRAMÁTICA: ANÁLISIS DE LAS RELACIONES LÓGICO-SEMÁNTICAS DE LA CONJUNACIÓN EN MEMES}

\section{Resumen}

Esta investigación está afiliada a los procedimientos teórico-analíticos de la Semiolingüística, con base en estudios de Charaudeau (1992), ya que esta propuesta permite una perspectiva más amplia de análisis de la enseñanza de lengua, lo que posibilita trabajar las relaciones lógicas en sus múltiples aspectos semántica. El objetivo de este estudio es analizar las relaciones lógicosemánticas de las conjunciones, especialmente, de la conjunción "y" en textos del género textual meme. Así, se observarán los sentidos que van más allá de los propuestos por la Gramática tradicional enseñada en las escuelas, considerando que la enseñanza de la lengua puede ser mucho más efectiva si se considera en sus diferentes contextos y usos. Se desarrollará un estudio sobre el género textual meme, observando su origen y características propias. En seguida, se abordarán algunos conceptos de la teoría semiolingüística y, por fin, un análisis de las operaciones lógicas, de acuerdo con lo que Charaudeau (1992) propone en su Gramática del Sentido y de la Expresión. La principal conclusión obtenida en este estudio, fue que una conjunción, u otra clase gramatical, no puede ser descrita y limitada a un único sentido, como ha sido hecho por las gramáticas tradicionales y utilizado por las escuelas de educación básica de Brasil. Esto es porque, a partir del uso, pueden ocurrir diversos efectos contextuales para el mismo elemento lingüístico.

Palabras clave: enseña; gramática; sentido; conjunación; meme 


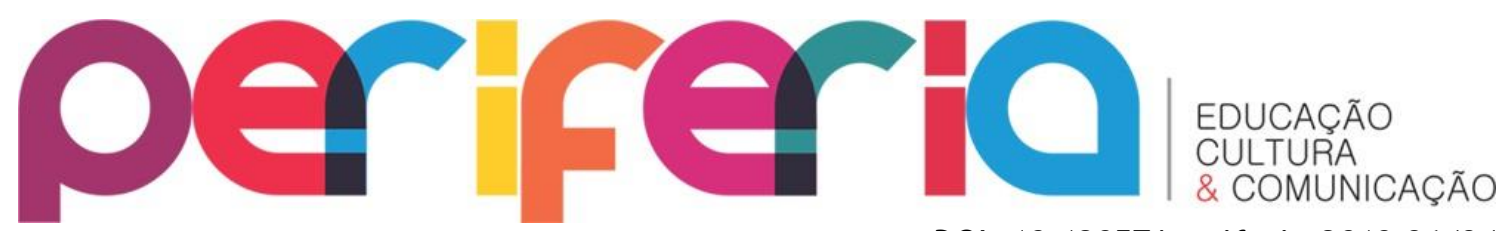

INTRODUÇÃO

Não se pode negar que o ensino de gramática do português brasileiro traz muitas questões aos linguistas, uma vez que se prioriza, em grande medida, a norma e a descrição em detrimento do uso real dos falantes da língua. Segundo Pauliukonis (2013), os estudos realizados sobre as variações linguísticas parecem ser esquecidos ou "ignorados" pelas escolas e também pelos livros didáticos utilizados na educação básica. Há, na verdade, uma insistência "na descrição e defesa de um ideal de norma única, que é exigido em exames e concursos, que não medem o potencial linguístico do usuário e, sim, sua capacidade de decorar regras obtusas ou inúteis" (PAULIUKONIS, 2013, p. 5).

Monnerat (2008) defende que, ao contrário do que faz a maioria das escolas em relação ao ensino de língua, o melhor seria "iniciar pela gramática internalizada, aproveitando a experiência que o aluno já traz em sua bagagem e, varrendo de vez o preconceito linguístico, passar pela gramática descritiva ou de usos, para finalmente se chegar à gramática normativa prescritiva" (MONNERAT, 2008, p. 123-124). Tudo isso, levando em conta uma ampla reflexão sobre a gramática.

A autora afirma ainda, retomando Perini (1995), que a "gramática reflexiva" seria aquela em que ocorre uma interseção texto e gramática, ou seja, os conteúdos não são dados como prontos, mas a partir de uma construção de um saber do próprio aluno, fazendo com que compreenda os mecanismos linguísticos e, assim, sendo capaz de passar das categorias do discurso às categorias da língua. Desta forma, há um aprendizado significativo de língua para os falantes nativos de português brasileiro.

Como exemplo disso, podemos citar a forma como as relações lógicas são comumente ensinadas, com "decorebas" de listas de conjunções e classificações de orações que possuem limitados sentidos, apagando-se outras inúmeras possibilidades de acordo com o uso de cada conjunção.

Sendo assim, considerando a proposta de Charaudeau (1992) de uma "Gramática do sentido e da expressão", a partir da perspectiva da Semiolinguística, este trabalho tem o objetivo de desenvolver uma análise das 


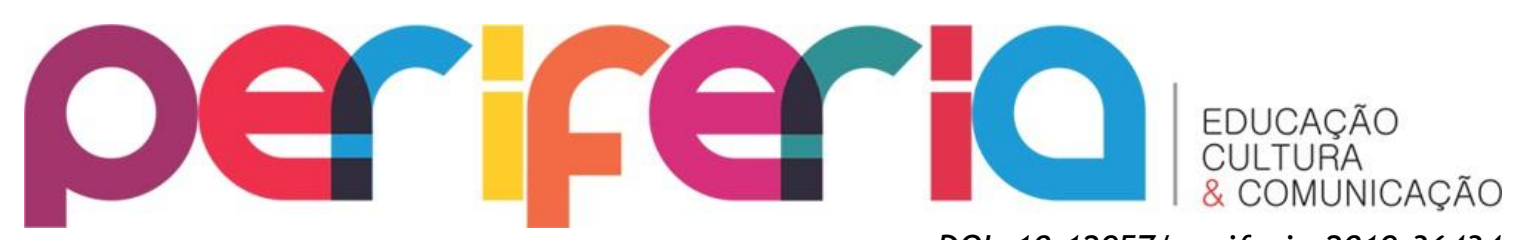

DOI: $10.12957 /$ periferia.2019.36434 relações lógico-semânticas. Observaremos como se dão as relações lógicosemânticas das conjunções, mais especificamente do relator $e$, em seus diferentes efeitos contextuais.

Nosso corpus de análise é composto por um conjunto de 18 memes que circulam nas redes sociais. Este gênero textual é acessível aos jovens que acessam as redes sociais frequentemente. Isto porque, como já mencionamos, consideramos que o ensino de gramática deve partir de uma vivência do aluno, de algo que ele domine e que, a partir disso, possa tirar suas próprias conclusões e seja capaz de dominar os mecanismos linguísticos da língua portuguesa.

Para isso, desenvolveremos brevemente um estudo sobre o gênero textual meme, observando sua origem e características próprias. Em seguida, discorreremos sobre alguns conceitos da teoria Semiolinguística que são relevantes para nossa pesquisa e, por fim, faremos uma análise das operações lógicas, de acordo com o que Charaudeau (1992) propõe em sua Gramática do Sentido e da Expressão. É nosso objetivo observar que os sentidos vão além dos propostos pela Gramática tradicional ensinada nas escolas e que o ensino da língua pode ser muito mais significativo se levado em conta o uso em seus diferentes contextos.

\section{OS MEMES}

O termo grego Meme significa imitação. Este conceito surgiu, primeiramente, no campo da biologia pelo zoólogo Richard Dawkins em 1976, quando escreveu seu livro "The Selfish Gene" (0 Gene Egoísta). Para Dawkins, "o meme é uma unidade de informação com capacidade de se multiplicar, através das ideias e informações que se propagam de indivíduo para indivíduo. Os memes constituem um vasto campo de estudo da Memética" (SIGNIFICADOS, 2017).

Com o avanço da internet, surgiram novas formas de comunicação e, consequentemente, de textos. Um deles é conhecido por meme, retomando o conceito de multiplicação de informações de Dawkins. Embora não haja uma definição específica para o termo utilizado na internet, geralmente se refere a 


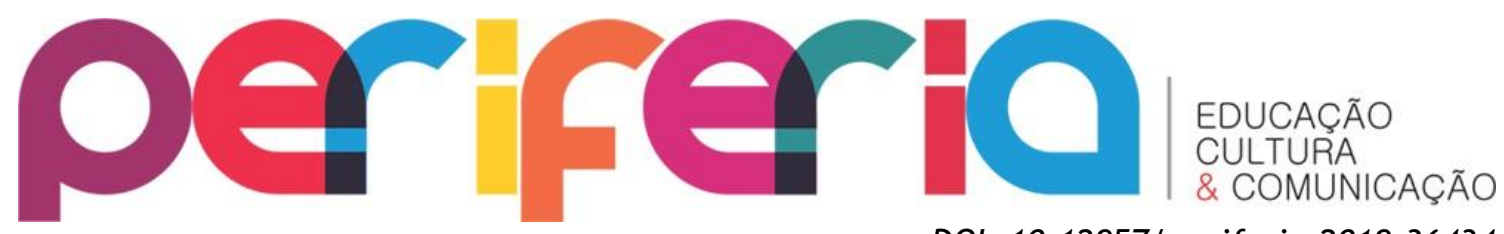

DOI: $10.12957 /$ periferia.2019.36434 “comentários, postagens de fotos, vídeos, paródias que são comumente relacionados a notícias do cotidiano provenientes em grande parte de outros canais midiáticos, sendo estes a televisão, os jornais impressos e o rádio" (SOUZA, 2013, p. 134). Ou seja, é uma viralização de informações que atinge a um grande número de pessoas rapidamente, trazendo humor, crítica, reflexões sobre variados temas atuais.

Desta forma, podemos dizer que este é um tipo de texto atual que se assemelha à charge. Em geral, trata de assuntos muito recentes e específicos, estando diretamente relacionado ao contexto situacional em que é produzido. Ou seja, para compreendê-lo, na maior parte das vezes, é necessário estar inserido na mesma cultura, no mesmo meio social e conhecer o assunto tratado.

Em trabalho de tese de doutorado, Barreto (2015) fez um estudo sobre memes que circulam no espaço virtual da internet. Nesta pesquisa, a autora afirma, segundo Benwell e Stokoe, (2006) que é possível compreender os memes como "performances significativas para seus participantes, a partir das quais eles podem criar/manter identidades individuais e coletivas, através de ideologias sociais e culturais compartilhadas” (BARRETO, 2015, p. 10).

Souza (2013) aponta que este tipo de texto traz mensagens a serem analisadas, interpretadas e, caso haja identificação, multiplicadas pelo receptor, tornando-se, assim, uma prática social dos nossos tempos:

Os textos mêmicos carregam em si mensagens que são decodificadas pelos cérebros receptores, analisadas, interpretadas, adotadas e, por vezes, replicadas, tal que, ao se familiarizarem com a linguagem contida no componente a ser replicado, estarão dialogando de certa maneira com o criador do "meme", ou mesmo com os partícipes das mesmas interações de transmissão de ideias. É a linguagem enquanto fenômeno social, como prática de atuação interativa (SOUZA, 2013, p. 134).

O autor afirma ainda que nós somos apenas "hospedeiros das ideias que saltam de cérebro para cérebro as quais estão em constante processo de recombinação e transformação na tentativa de sobrevivência” (SOUZA, 2013, p. 132). Sendo assim, para que as ideias sobrevivam, elas precisam da identificação do receptor que agirá na sua transmissão. 


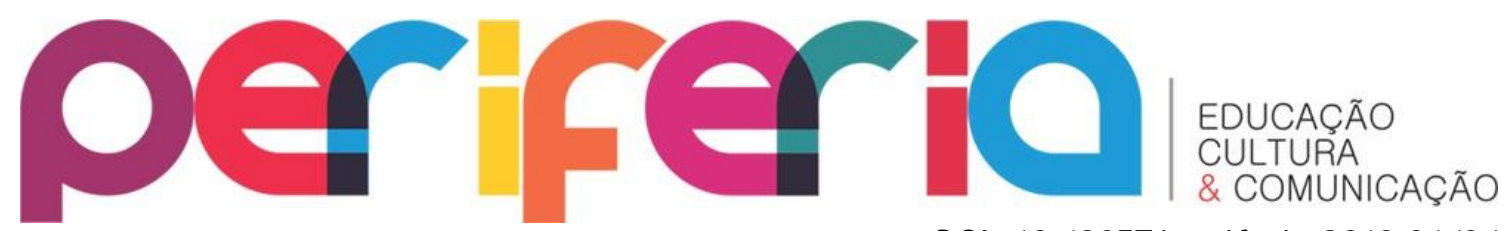

DOI: $10.12957 /$ periferia.2019.36434

Tudo o que pode ser aprendido através da cópia é um meme; (...) todo o conhecimento adquirido por réplica, tudo aquilo observado e imitado é considerado meme, como os hábitos, os valores, os padrões estéticos e qualquer produto cultural difundido. Uma vez copiado, o meme ajuda na implantação de crenças e valores, ganhando mais força a cada novo hospedeiro e garantindo sua autenticidade por meio da familiaridade (MORAES, MENDES E LUCARELLI, 2011, p. 5-6).

Nesta medida, observamos que há um contrato de comunicação entre os parceiros em relação à publicação e compartilhamento de memes na internet, seja na forma de postagens ou comentários. Para que ele faça sentido e viralize na internet, deve, pois, cumprir com este contrato, isto é, representar a realidade em forma de um texto, que, normalmente, assimila linguagem visual e verbal, e que, na maior parte das vezes, são indispensáveis para sua compreensão.

Tem-se, assim, um processo de semiotização do mundo, em que o sujeito tem a intenção de falar, geralmente em forma de ironia, humor ou crítica sobre o mundo que o cerca, trazendo a "mímese", os memes, que podem também representar uma identidade individual ou social. Poderíamos também falar de uma memetização do mundo, ou seja, uma significação do mundo através de memes.

\section{A TEORIA SEMIOLINGUÍSTICA E ALGUNS CONCEITOS}

A Teoria Semiolinguística surgiu na década de 1980, com estudos desenvolvidos pelo linguista Patrick Charaudeau, na França, desenvolvendo-se também em terras brasileiras, tornando-se, então, uma construção entre estudiosos dos dois países (CORRÊA-ROSADO, 2014). “A teoria, francesa de origem, teve assim que se acomodar aos trópicos. E saiu enriquecida como saem todos aqueles que viajam pelo mundo e se adaptam a novas culturas, novos olhares" (MACHADO, 2010, p. 223).

Machado (2006) aponta o caminho percorrido por Charaudeau na elaboração teórica da Semiolinguística, trazendo a questão do sujeito não 


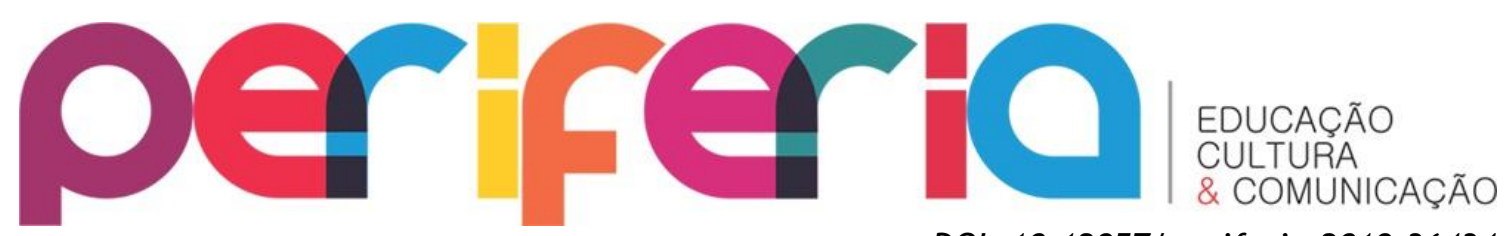

DOI: $10.12957 /$ periferia.2019.36434 assujeitado, um sujeito histórico como um ponto forte desta formulação desenvolvida pelo autor:

Patrick Charaudeau elaborou, de modo consciente ou não, uma junção de conceitos vindos de Benveniste com outros vindos de Bakhtin, chegando então a conceber um dos pontos inovadores da citada teoria: a volta do "sujeito", conceito que havia sido completamente "pulverizado" por Barthes, nos anos 60 e depois, de certa forma, por Pêcheux e seus seguidores. Estamos nos referindo aqui, é claro, não ao "sujeito-assujeitado" de quem fala Foucault, mas, ao sujeito histórico, com suas idiossincrasias e crenças e também com o seu "estilo" (MACHADO, 2006, p 14).

$\mathrm{Na}$ Teoria Semiolinguística, leva-se em conta um sujeito intencional, que articula a língua em diferentes níveis de modo a fazer cumprir seu ato de linguagem. Ela insere "o discurso em uma problemática comunicacional e pragmática, o que permite uma ênfase na questão dos sujeitos da linguagem e de suas intencionalidades" (CORRÊA-ROSADO, 2014, p. 2). Este sujeito é dono de si mesmo, não sendo assujeitado. Sua intencionalidade faz com que se forme sua identidade, uma vez que faz as suas próprias escolhas.

$\mathrm{O}$ ato de linguagem, de acordo com a teoria, traz sempre um sujeito (EU/TU) que se dirige a um outro sujeito (TU/EU). Este sujeito está no mundo, articulando meios linguísticos e discursivos para cumprir sua finalidade comunicacional, de forma a dar sentido às coisas do mundo, isto é, à semiotização do mundo.

$\mathrm{O}$ ato de linguagem não pode ser concebido de outra forma a não ser como um conjunto de atos significadores que falam o mundo através das condições e da própria instância de sua transmissão. De onde se conclui que o Objeto do Conhecimento é o do que fala a linguagem através do como fala a linguagem, um constituindo o outro (e não um após o outro) (CHARAUDEAU, 2014, p. 20; grifos do autor).

É através do ato de linguagem que se pode significar o mundo em vários aspectos. Este ato corresponde a um duplo processo de semiotização do mundo, que Charaudeau (1992) chama de transformação e de transação. O processo de transformação é aquele em que o falante dá sentido ao mundo através de sua 


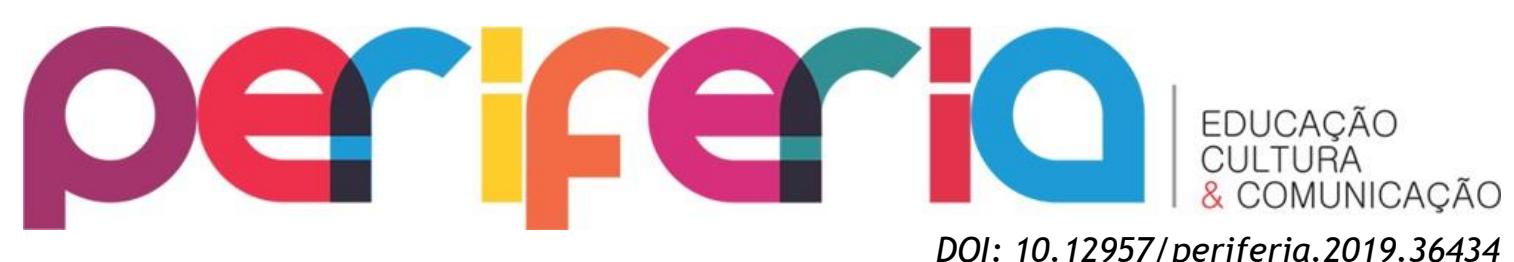
identificação, de sua qualificação, suas ações e causas. Só é possível atribuir sentido às coisas do mundo porque há a possibilidade de nomeá-las, caracterizálas, etc. Já o segundo processo, a transação, corresponde a um mundo já significado que será dividido com o outro, isto é, há um movimento de alteridade, de troca, fazendo conexões e relações entre as coisas do mundo.

Para que se cumpra o ato de linguagem, há de haver um contrato firmado entre os parceiros, sendo, portanto, um conjunto das condições em que se realiza todo e qualquer ato de comunicação, que é sempre uma aposta e só se cumpre se houver o acordo do contrato estabelecido.

No momento em que um ato de linguagem acontece, devem-se considerar os contextos situacionais e a intenção dos falantes, para que ele seja possível. Sendo assim, Charaudeau (1992) propõe uma "Gramática do sentido e da expressão", em que importa pensar nas diferentes relações semânticas que podem ser adquiridas no uso da língua, não como algo estático e imutável, mas considerando as diferentes situações comunicativas, nas intenções dos falantes e nos possíveis efeitos discursivos trazidos no ato de linguagem. Deste modo, leva-se em conta que a palavra não tem apenas um sentido, mas efeitos de sentidos possíveis dependendo de suas condições de uso.

Charaudeau (1992), em um estudo sobre as relações lógico-semânticas em sua "Gramática do sentido e da expressão", apresenta-nos cinco categorias em que se dividem essas relações: a conjunção, a disjunção, a restrição, a oposição e a causalidade.

Não trataremos aqui de todas estas categorias, já que neste trabalho, como já dissemos, interessa-nos observar, como um recorte, alguns possíveis efeitos contextuais para a categoria da conjunção em memes que circulam pela internet, nas redes sociais, sobre diversos assuntos. Desta forma, trataremos agora das relações lógicas.

\section{OPERAÇÕES LÓGICAS}

É preciso retomar aqui que a gramática tradicional não dá conta das relações lógicas em seu uso, uma vez que se baseia apenas nos aspectos 


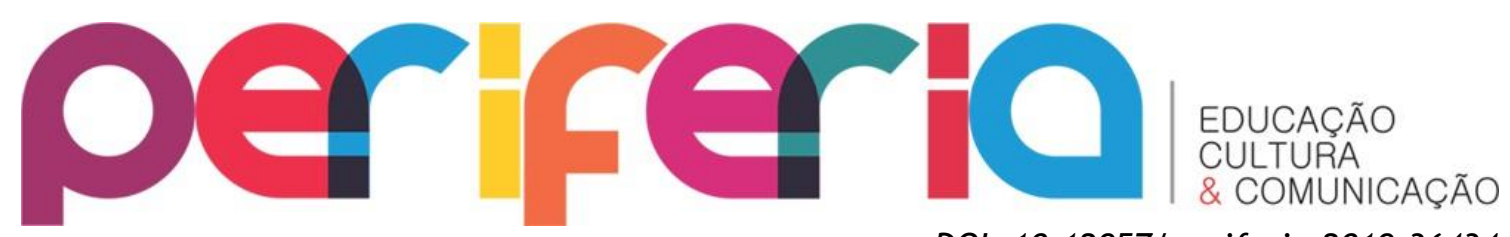

DOI: $10.12957 /$ periferia.2019.36434 formais, isto é, em suas marcas linguísticas, sem considerar os elementos externos à língua. 0 que se vê, na verdade, é uma apresentação dessas relações por meio de classificação de orações, em que aparece uma lista de conjunções que são apenas decoradas e não se reflete sobre os sentidos possíveis para elas.

Segundo Oliveira e Monnerat (2005), há uma preocupação de professores e linguistas nesta forma de ensino que tem sido ofertada aos alunos da educação básica. Busca-se, com isto, que os alunos "possam refletir sobre as possibilidades semântico-discursivas das marcas linguísticas que deverão utilizar" (OLIVEIRA; MONNERAT, 2005, p. 90).

Para Charaudeau (1992), as operações lógicas consistem em articular duas ou mais asserções sobre o mundo à nossa volta, fazendo com que haja uma relação de dependência entre a existência de uma e de outra asserção. Isto se dá por meio de uma operação de pensamento, que constrói relações de sentido com as coisas do mundo, o que permite haver uma ligação entre as asserções, isto é, a relação lógica.

\section{As conjunções}

Charaudeau (1992) afirma que, geralmente, as conjunções nos são apresentadas na escola em grupos específicos de palavras, associadas às classificações de orações coordenadas e subordinadas.

A conjunção não é definida, do ponto de vista da semiolinguística, como “um tipo de palavra gramatical”, como na Gramática Tradicional, mas como uma operação lógico-semântica. A conjunção, para Charaudeau, é uma operação que consiste em ligar as asserções. Essa ligação pode ocorrer de maneira interna ou externa às asserções (CHARAUDEAU, 1992).

Quando essa ligação ocorre de maneira interna, as asserções são unidas de modo que o elemento idêntico seja "fator comum" a todos os outros elementos, que pode se referir a três diferentes movimentos:

Primeiramente, quando um mesmo ser que é qualificado por várias características, como podemos observar na imagem 1 que segue: 


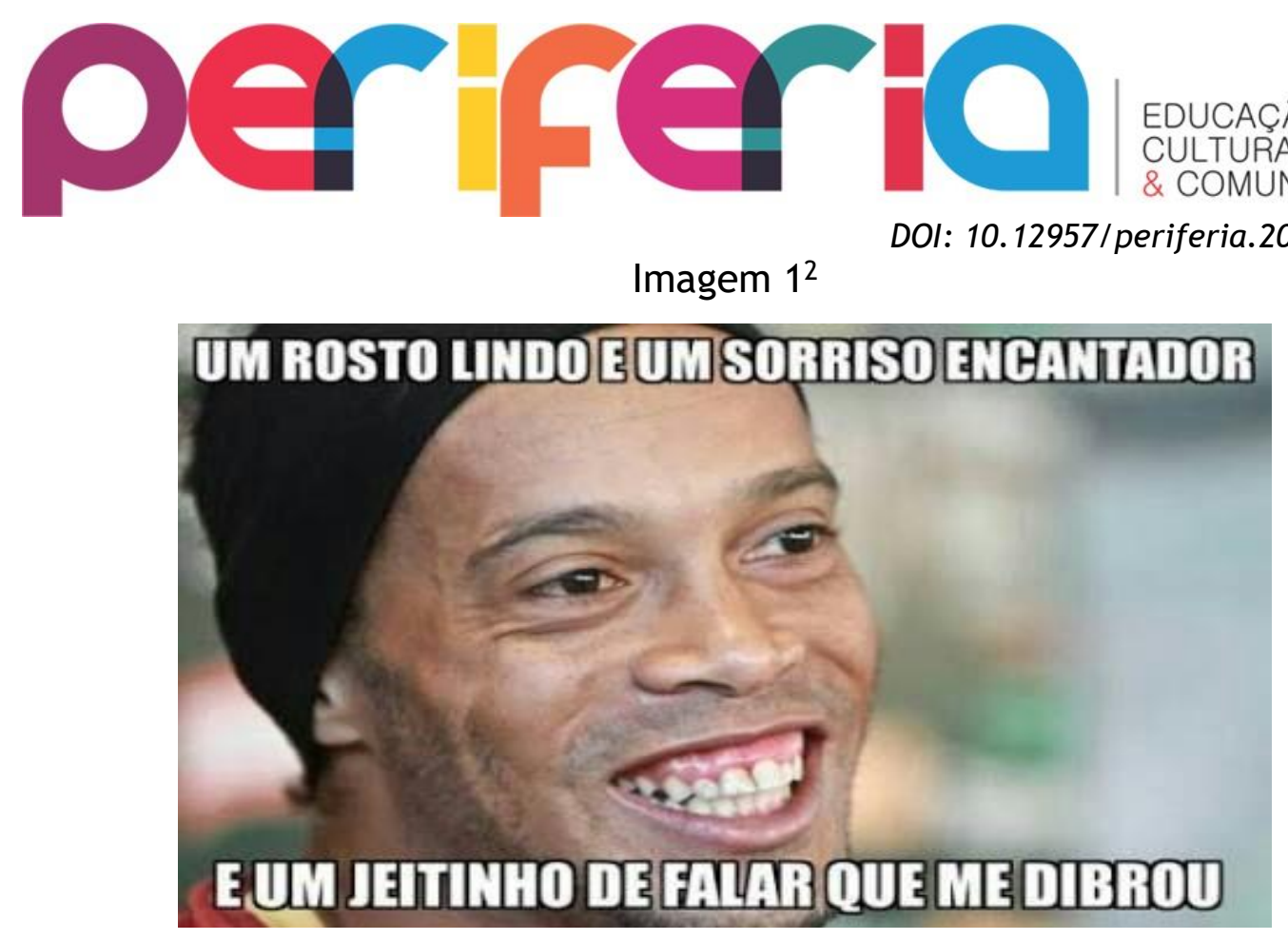

Neste caso, o sujeito não aparece na linguagem verbal, apenas na imagem do jogador Ronaldinho Gaúcho. E este sujeito recebe várias características que são ligadas pelo conector "e": "um rosto lindo $e$ um sorriso encantador $e$ um jeitinho de falar que me 'dibrou'”. É importante ressaltar, ainda nesta imagem, que o gênero textual meme utiliza, normalmente, uma linguagem coloquial, próxima do modo informal da língua, como vemos em 'dibrou' em vez de 'driblou', visto que este tipo de texto é criado por pessoas em diversas situações, com diversos objetivos. Assim, a linguagem representada neste tipo de texto é a linguagem próxima ao uso real dos falantes.

Um outro movimento de ligação interna ocorre quando um mesmo ser desempenha o papel de agente de várias ações, ou mesma ação que remeta a pacientes diferentes:

\footnotetext{
${ }^{2}$ Todas as imagens de memes foram encontradas em pesquisa realizada no Google, estando, portanto, em domínio público.
} 


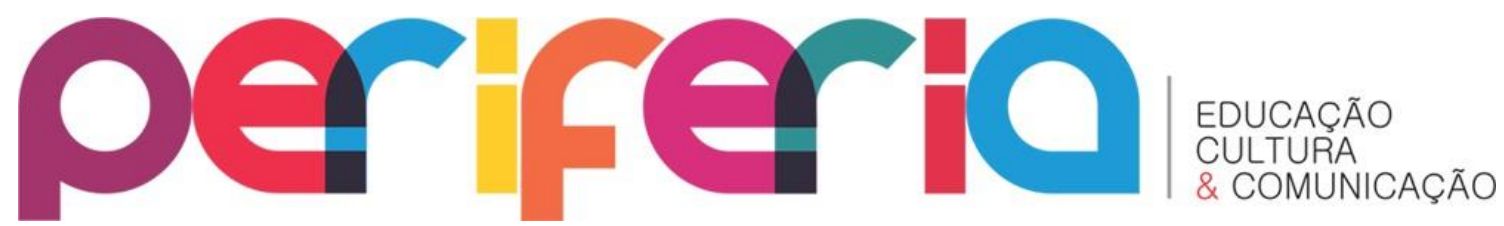

Imagem 2

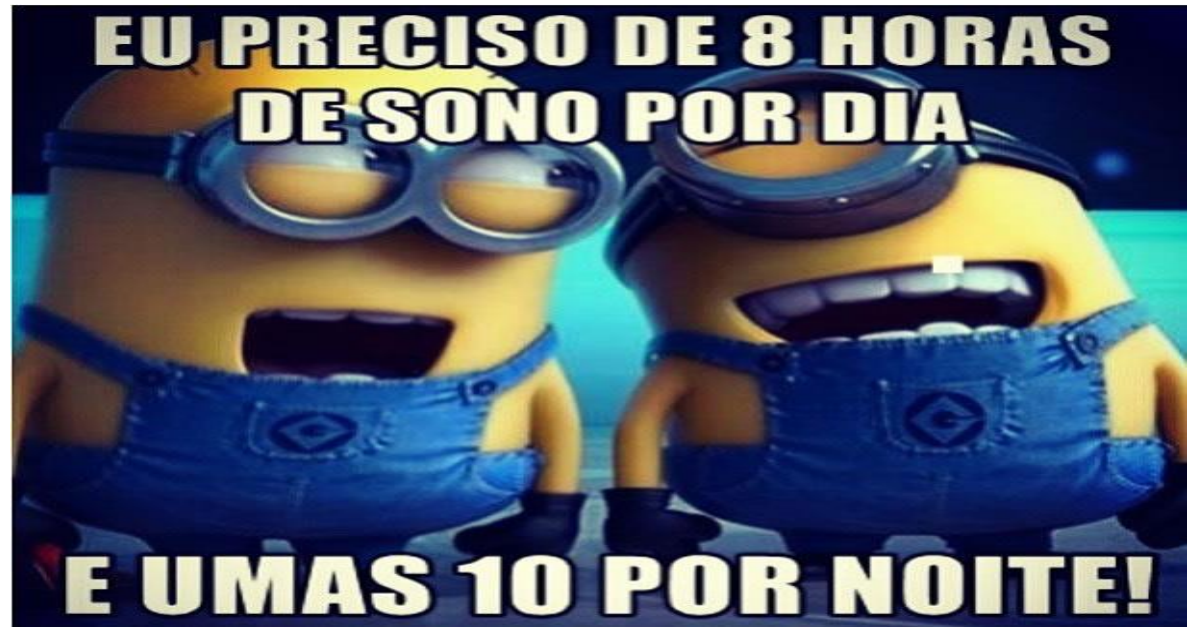

$\mathrm{Na}$ imagem 2, podemos verificar em "Eu preciso de 8 horas de sono por dia e umas 10 por noite!" um mesmo ser (eu) que representa duas ações: precisar de 8 horas de sono por dia e precisar de 10 horas de sono por noite.

O terceiro caso de ligação interna pode ser observado quando uma mesma característica é atribuída a dois seres distintos, como ocorre na imagem 3: Os seres "Eu e você" são qualificados como "amigos".

Imagem 3

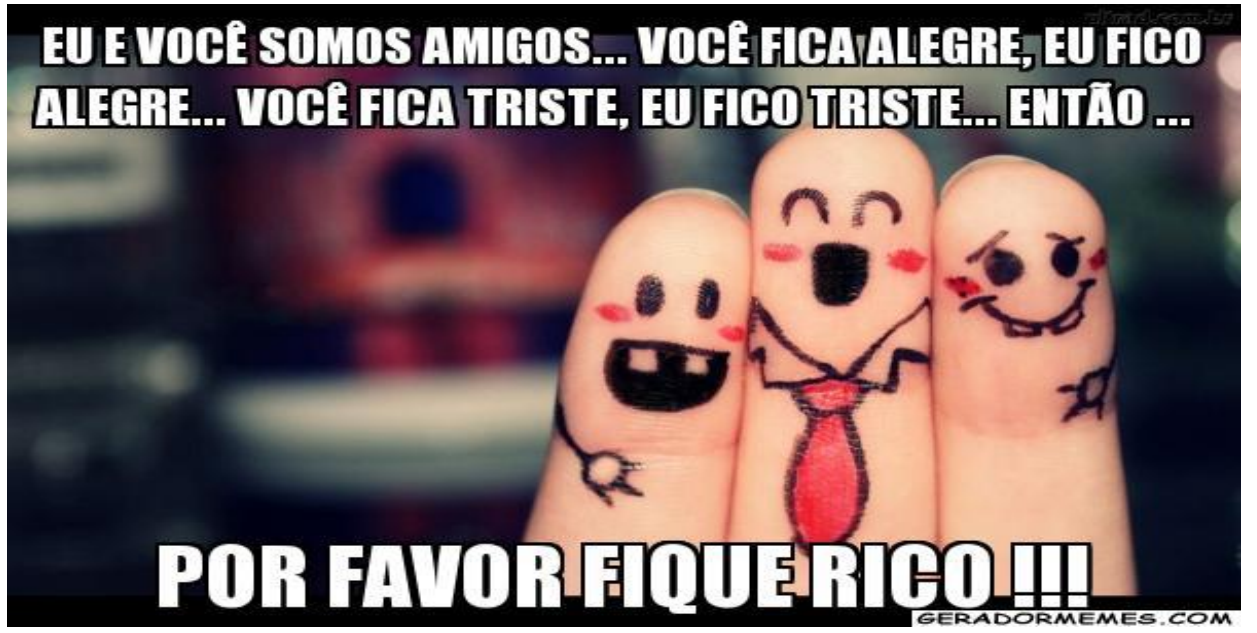

Quando se trata de uma ligação externa, Charaudeau (1992) aponta que há a intenção de aproximar as asserções e colocá-las em relação uma à outra, 


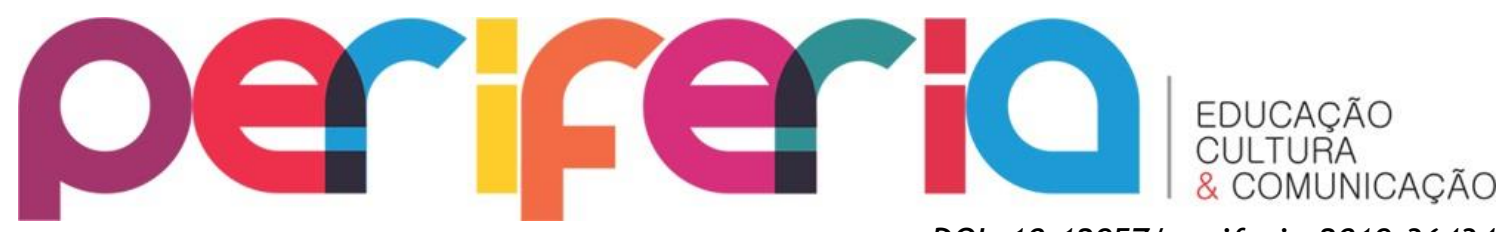

DOI: $10.12957 /$ periferia. 2019.36434 trazendo, nesta aproximação, um sentido de comparação, oposição, concessão, simultaneidade, consequência, etc, como veremos mais adiante.

O relator $e$ (et) é a marca privilegiada desta relação lógico-semântica. Em um contexto negativo podemos ter o nem (ni) e, em uma associação, o com (avec).

Quando há a repetição de um relator, substituindo a pontuação, por exemplo, traz-se um efeito de autonomia aos elementos e, desta forma, uma relação de sucessão às asserções, como vimos na imagem 1: “Um rosto lindo $e$ um sorriso encantador $e$ um jeitinho de falar que me 'dibrou'”. Neste caso, a conjunção $e$ isola os elementos qualitativos das asserções, mostrando uma relação de independência.

Isto também ocorre no caso da negativa, quando é utilizado o relator nem, como podemos observar a seguir:

Imagem 4

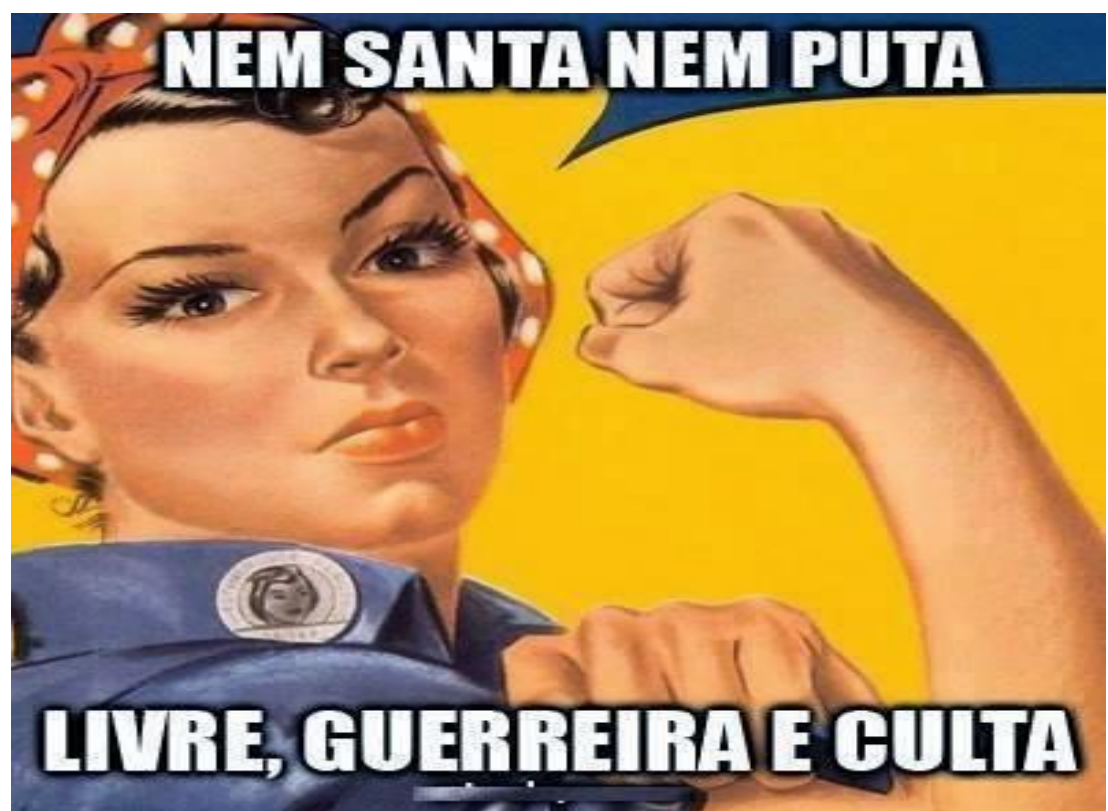

$\mathrm{Na}$ imagem 4, podemos verificar que o relator nem, bem como o $e$, no exemplo anterior da imagem 1, traz uma autonomia às caraterísticas apresentadas em relação ao sujeito. Observa-se, inclusive, que a vírgula desaparece no momento da segunda aparição do conector nem, o que já demonstra um desligamento entre ambas as asserções. 


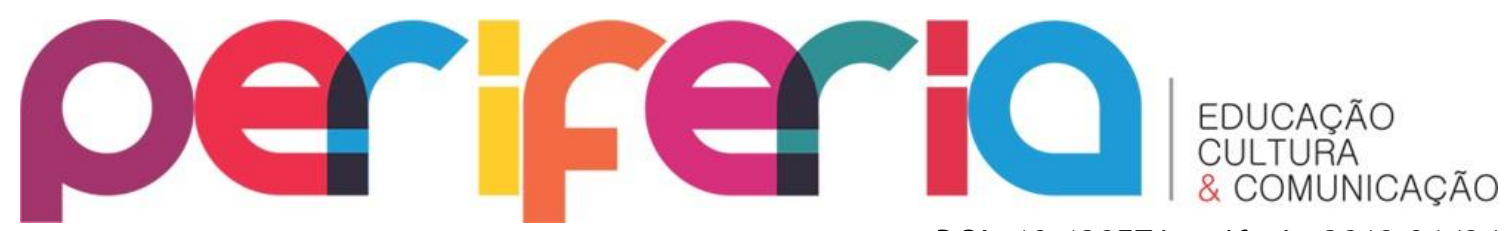

DOI: $10.12957 /$ periferia. 2019.36434

Vejamos agora as particularidades semânticas de que nos fala Charaudeau (1992) e a análise de cada exemplo.

\section{PARTICULARIDADES SEMÂNTICAS}

Charaudeau (1992) afirma que a relação lógica das conjunções é causada pela combinação de uma operação lógico-semântica juntamente com um tipo de ligação entre os elementos. Isto resulta em três subcategorias, que o autor define como: adição, associação e reciprocidade, das quais trataremos a seguir trazendo exemplos de memes correspondentes aos três casos.

A subcategoria da adição corresponde aos elementos que estão inseridos em um mesmo plano de igualdade, isto é, podem ser acrescentados um ao outro por uma determinada semelhança. Isto pode ser visualizado nos memes das imagens 5 e 6 a seguir:

Imagem 5

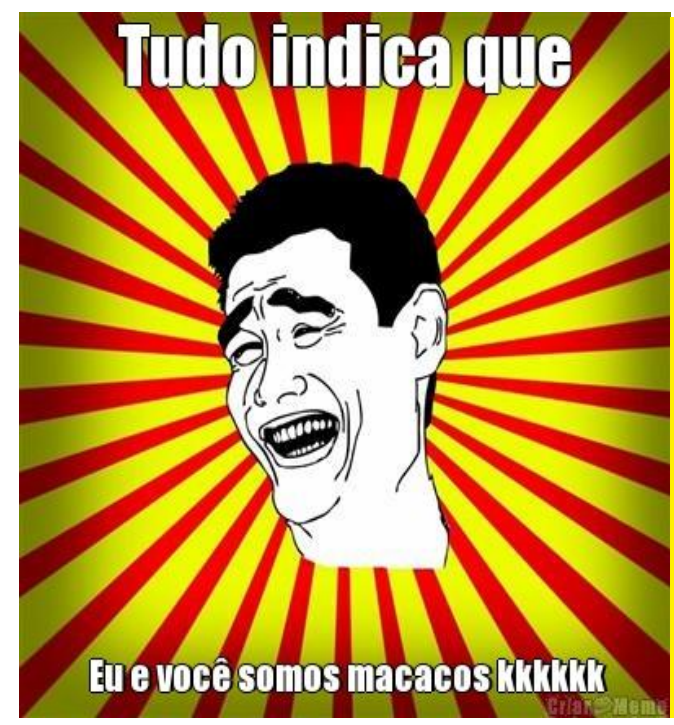

Imagem 6

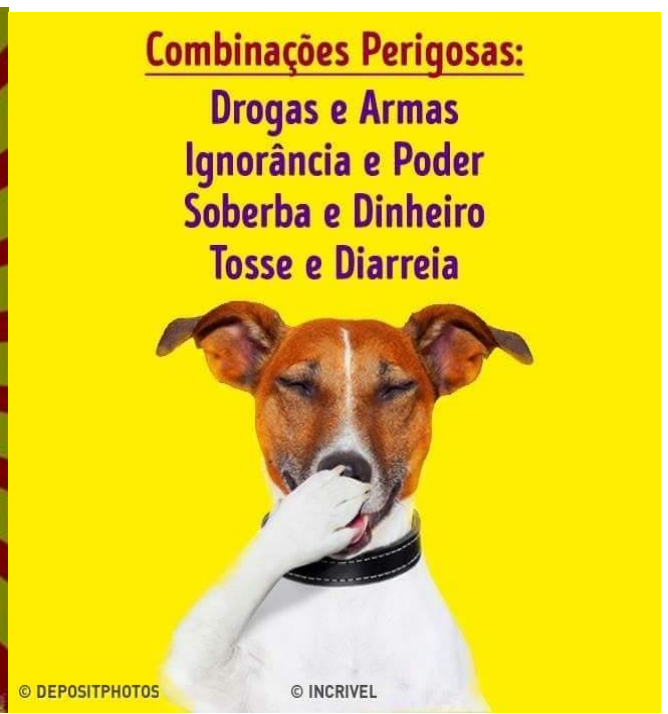

Na imagem 5, a frase "eu e você somos macacos" traz uma característica comum aos dois seres aos quais se refere, estando ambos, portanto, em um lugar equiparado, como nos aponta Charaudeau. 0 mesmo ocorre na imagem 6, em que são apresentadas, em paralelismo, algumas “combinações perigosas”, que são adicionadas à lista pelo relator $e$, por estarem no mesmo plano, mas 


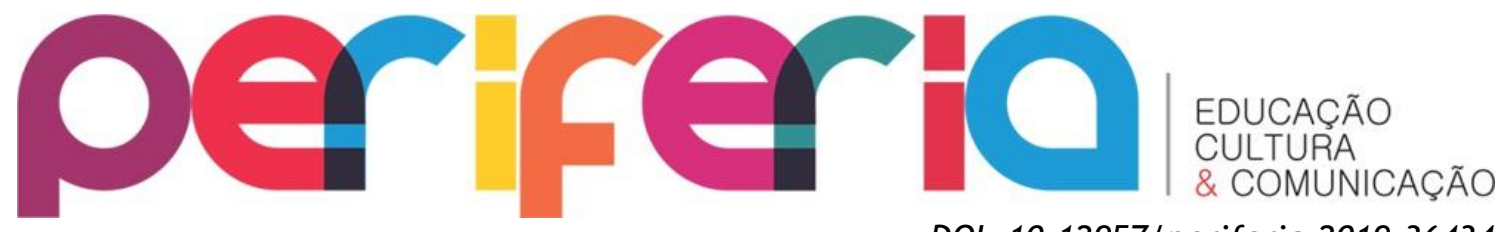

DOI: $10.12957 /$ periferia.2019.36434 que, na verdade, não deveriam estar, por serem combinações que não devem ocorrer: "Drogas e armas/ Ignorância e Poder/ Soberba e dinheiro/Tosse e diarreia".

No caso da associação, não há correspondência de igualdade. Há uma associação hierárquica, que coloca um elemento em relação de dependência a outro, ou seja, em que um elemento só existe porque há correspondência ao segundo.

A Associação é normalmente marcada pelos termos: com, acompanhado de, em companhia de, entre outros.

$\mathrm{Na}$ imagem seguinte (7), podemos observar a subcategoria da associação. No enunciado "você se aprontando para ir ao cinema com seus amigos" o marcador com traz esta relação hierarquizada entre as asserções. Desta forma, temos um elemento em dependência do outro marcado na conjunção com. 0 sujeito (você) irá ao cinema, mas não sozinho, irá acompanhado dos amigos.

Imagem 7

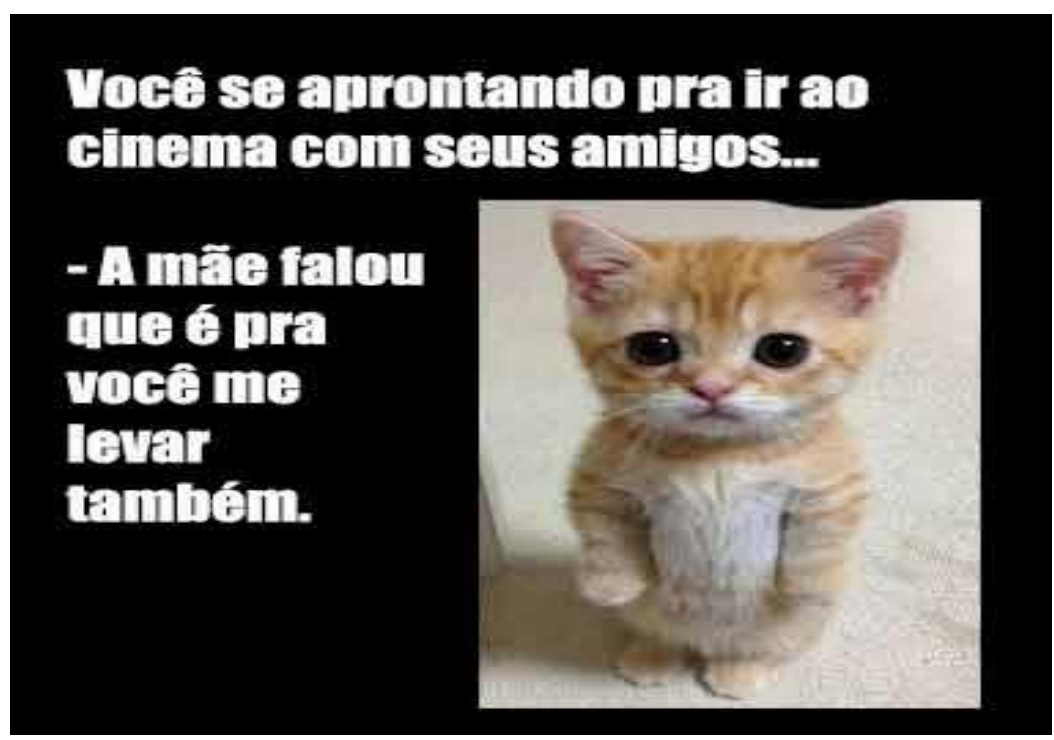

A reciprocidade se dá quando a operação da conjunção se aplica às asserções em que os sujeitos actantes desempenham funções simétricas, em uma reversibilidade de ações, ou seja, atuam mutuamente. Isso só é possível com actantes humanos, normalmente, já que ambos são agentes. 


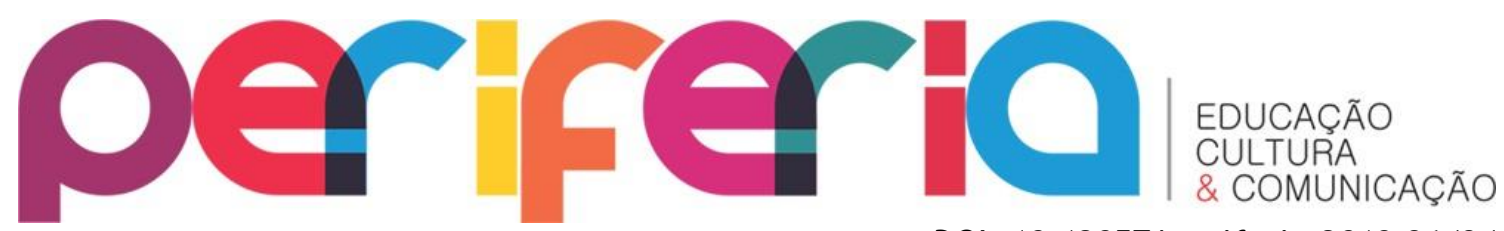

DOI: $10.12957 /$ periferia.2019.36434

Pode-se observar esta reciprocidade no meme que segue (imagem 8 ) em que os dois actantes (Eduardo e Mônica) "trocaram" contatos "e decidiram se encontrar". No caso do primeiro verbo trocar, já há uma indicação desta reciprocidade na semântica da própria palavra, enquanto no segundo caso, vemos o uso do elemento "se" para indicar a ação recíproca da decisão dos dois em relação ao encontro entre eles.

É importante mencionar aqui que os memes também têm, como uma de suas características, além de referências do cotidiano, o uso de intertextualidades, como letras de canções, poemas, documentos, textos não verbais, entre outros diversos tipos de textos.

Isto pode ser verificado na imagem 8 , em que há uma referência à canção "Eduardo e Mônica" do grupo Legião Urbana. Cria-se uma intertextualidade, trazendo os personagens (sujeitos actantes) e suas ações para tempos atuais, atualizando a forma de comunicação utilizada na atualidade.

A letra da canção diz que: "Eduardo e Mônica trocaram telefone, depois telefonaram e decidiram se encontrar”, já que na década de 80 , quando foi lançada pelo grupo, este era o meio de comunicação utilizado habitualmente. Hoje, com o avanço da internet e dos aparelhos eletrônicos, existem diversas formas de conectar-se ao outro além do telefone, como os mencionados no meme: "Skype, twitter, instagram, facebook, whatsapp".

\section{Imagem 8}

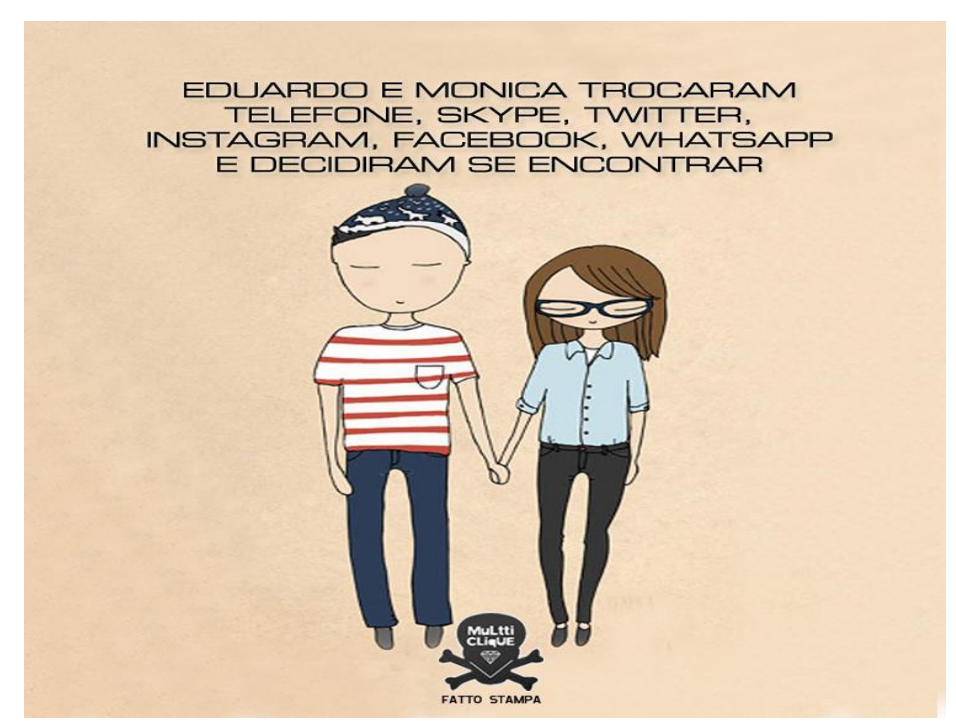




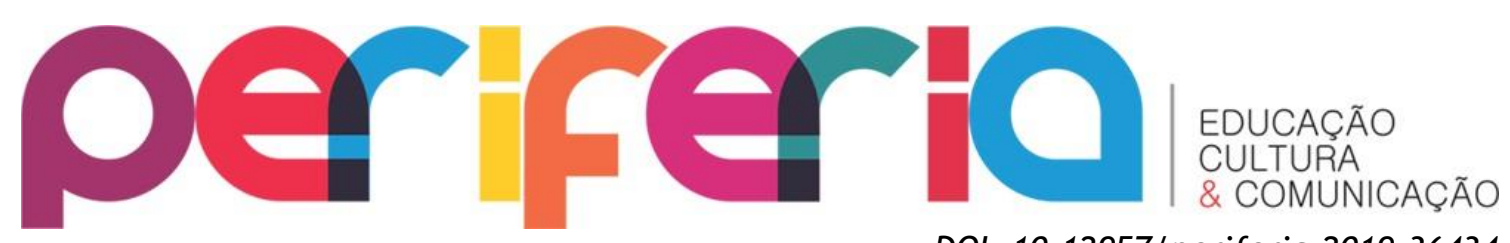

DOI: $10.12957 /$ periferia.2019.36434

\section{FATOS DE DISCURSO}

Os fatos de discurso são, segundo Charaudeau (1992), a descrição de qualquer efeito contextual. Os efeitos contextuais são resultado de uma combinação de elementos que podem ter diferentes relações dependendo das palavras em variados contextos. Assim, o autor define os seguintes efeitos: equivalência, acréscimo, sucessividade, simultaneidade, oposição, restrição, consequência, aproximação.

Vejamos agora um exemplo de cada um destes fatos do discurso, observando que os efeitos contextuais das conjunções podem ser múltiplos, uma vez que se deve considerar não apenas a marca linguística de forma isolada ou com sentido único, mas com um olhar amplo, que garante ao leitor uma melhor compreensão do texto lido.

É preciso lembrar que, parte-se sempre do proposto pela gramática tradicional, mas que ela por si só não basta. É necessário ampliar a visão sobre o texto, observar o interno e o externo à língua, como nos propõe Charaudeau (1992) com sua Gramática do sentido e da expressão, para, desta forma, compreendermos seus possíveis sentidos.

0 primeiro efeito contextual mencionado pelo autor é o de equivalência. Neste caso, há um movimento que faz com que haja uma relação de equivalência entre a primeira asserção e a segunda, ou seja, uma correspondência, como podemos observar na imagem 9. 


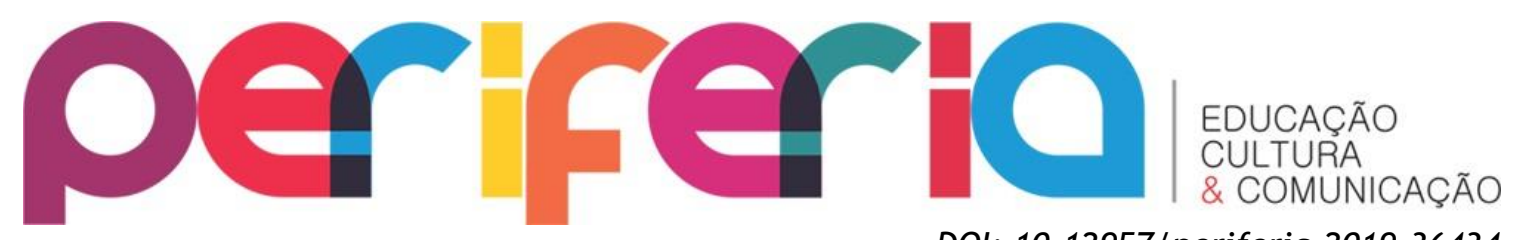

Imagem 9

DOI: 10.12957/periferia.2019.36434

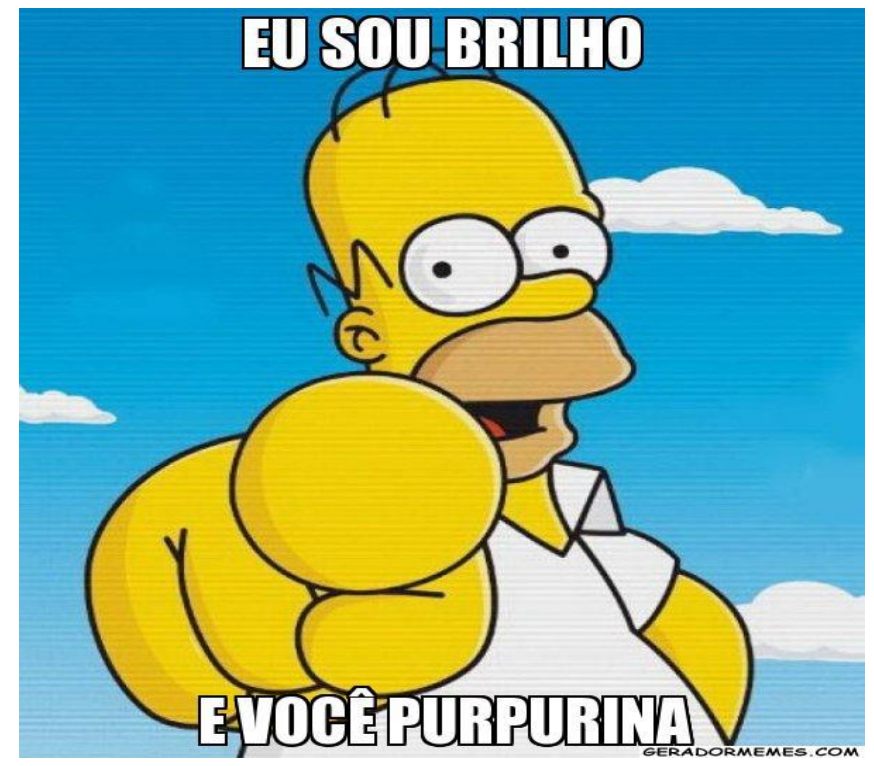

O meme da imagem 9 afirma: "Eu sou o brilho e você purpurina". Podemos dizer que não é apenas conjunção $e$ que traz esta relação, mas também o jogo de palavras que pertencem ao mesmo campo semântico "eu" e “você”, “brilho” e “purpurina” em uma formulação que estabelece um paralelismo em sua estrutura e, consequentemente, uma equivalência.

Outra relação lógico-semântica apontada por Charaudeau (1992) é a de acréscimo. Neste caso, acrescenta-se uma informação à outra por meio da conjunção. Como podemos observar a seguir:

Imagem 10 Imagem 11

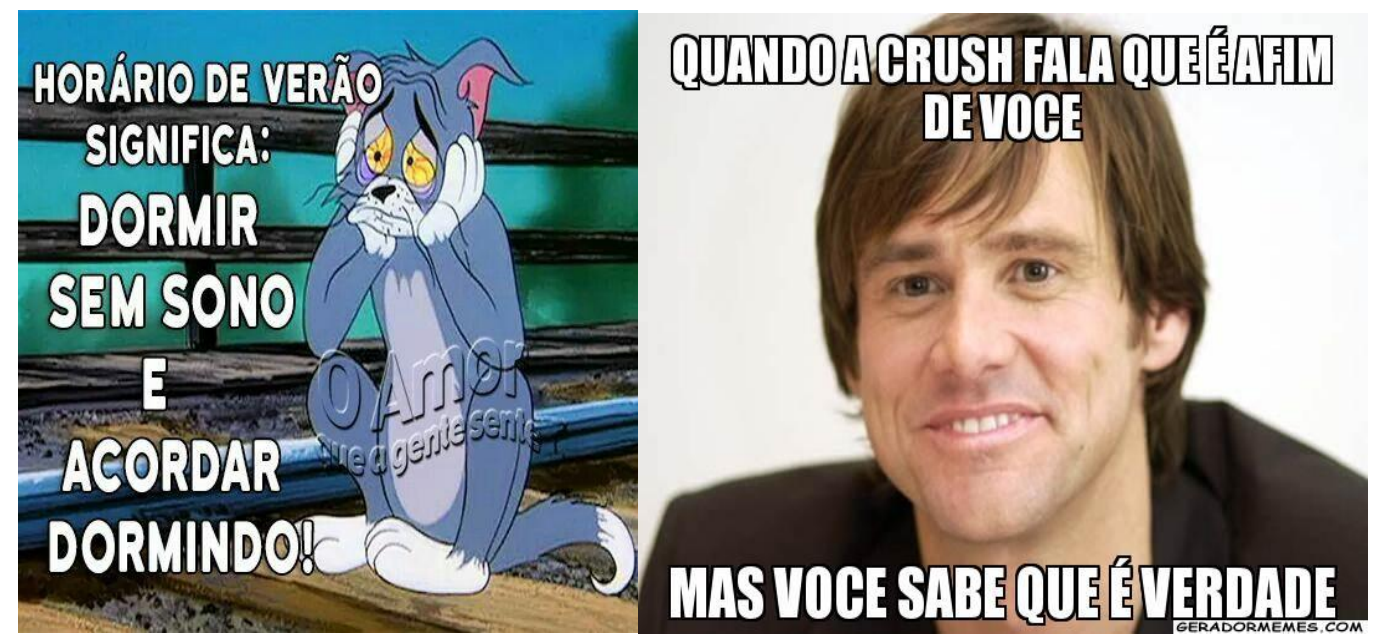




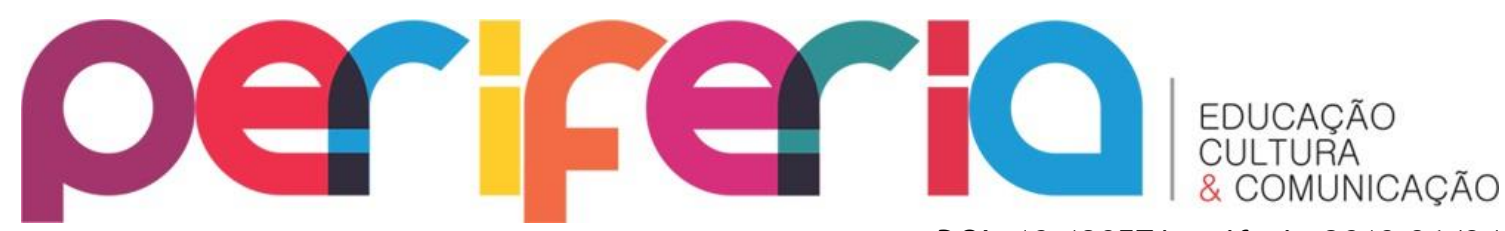

DOI: $10.12957 /$ periferia.2019.36434

$\mathrm{Na}$ imagem 10, o meme sobre o horário de verão diz que este horário significa: "dormir sem sono e acordar dormindo", isto é, são dois acontecimentos que se somam para explicar o que ocorre quando o horário de verão está em vigor.

Da mesma forma, vemos no segundo exemplo. 0 meme (imagem 11) tem o mesmo valor de acréscimo. No entanto, neste texto, utiliza-se a conjunção "mas" com valor de "e": "Quando a crush fala que é afim de você/ mas você sabe que é verdade".

Vejamos agora a imagem 12 que segue:

Imagem 12

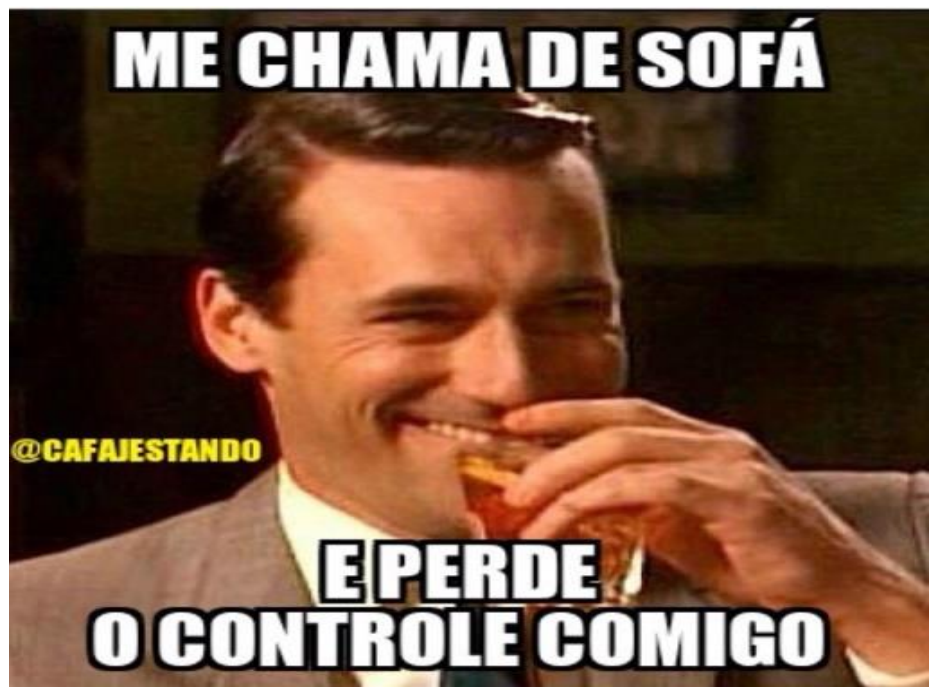

O meme acima é um exemplo de sucessividade. Nesse caso, há uma relação entre uma asserção e outra que indica que uma ação ocorre na sequência da outra, ou seja, há uma marcação temporal na ação indicada no enunciado: "Me chama de sofá e perde o controle comigo".

Ainda pensando na questão da temporalidade, Charaudeau (1992) apresenta outra relação lógico-semântica das conjunções: a simultaneidade. Se no caso anterior uma asserção e outra possuem uma temporalidade sucessiva, na simultaneidade esta relação ocorre concomitantemente. Isto pode se dar tanto em relação às ações quanto às características dos seres, como vemos nos exemplos que seguem das imagens 13 e 14 . 


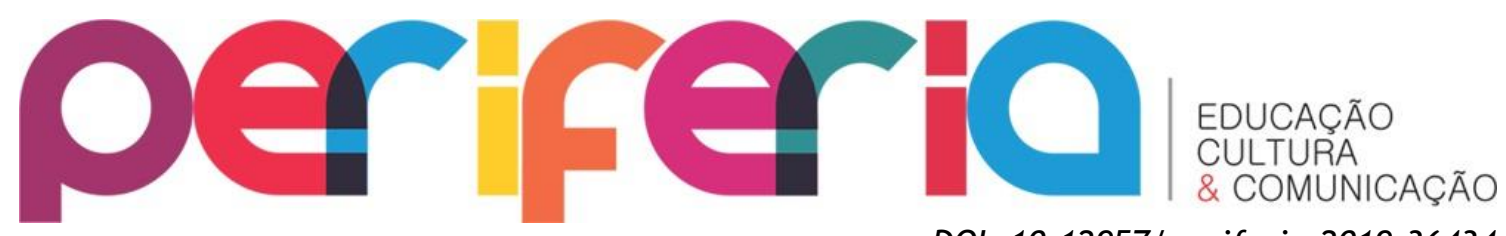

DOI: 10.12957/periferia.2019.36434

No primeiro exemplo (imagem 13), o meme diz: "a pessoa é doida, bipolar, sei lá o que e ainda se acha/ fazer o que né, pessoa assim é sempre amarga e infeliz". Temos aqui dois exemplos de simultaneidade de características do ser ao qual se referem. Os adjetivos são colocados lado a lado, separados por vírgulas e, no fim da oração, usa-se a conjunção $e$.

Assim também ocorre no caso da imagem 14, mas o uso da vírgula não acontece. Utiliza-se, em cada linha, uma característica e a última característica é conectada pelo relator e: "belas/ recatadas $e$ do lar" trazendo também a simultaneidade de características atribuídas ao ser.

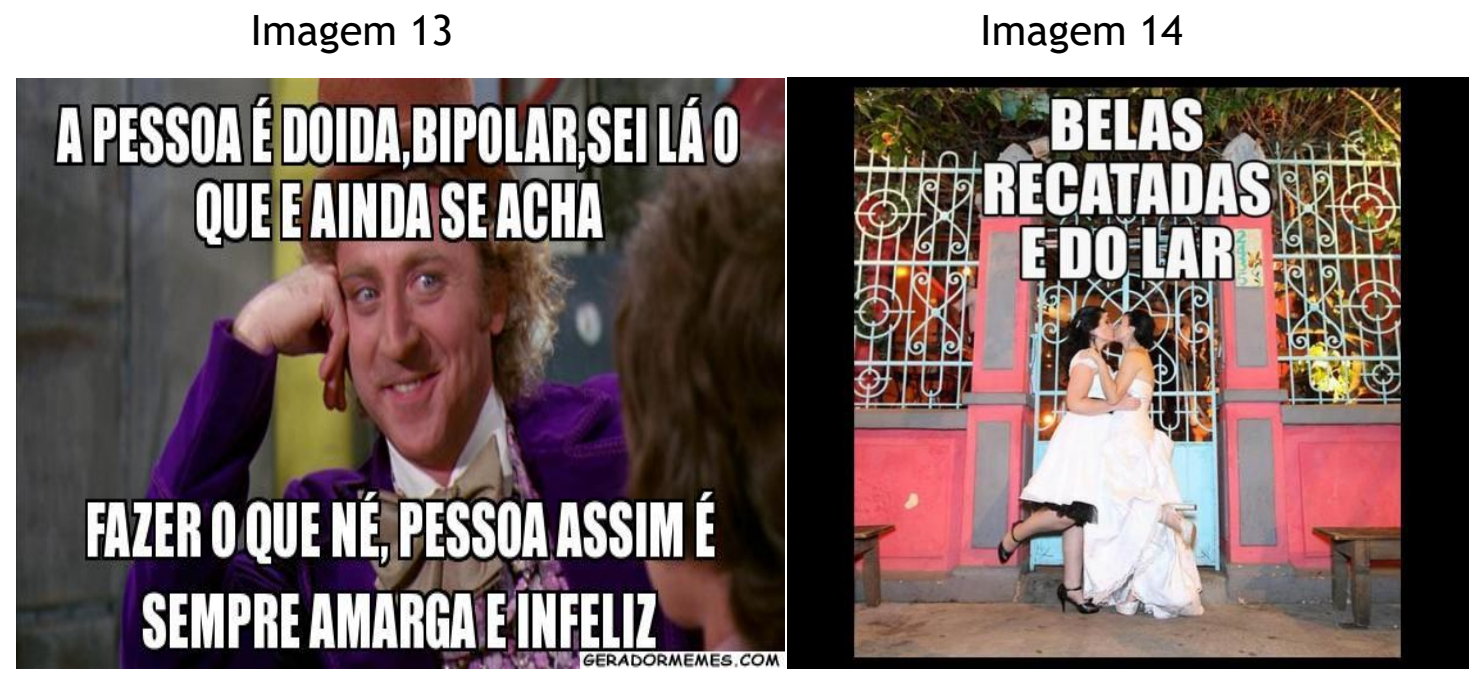

Vejamos agora a imagem 15 seguinte: 


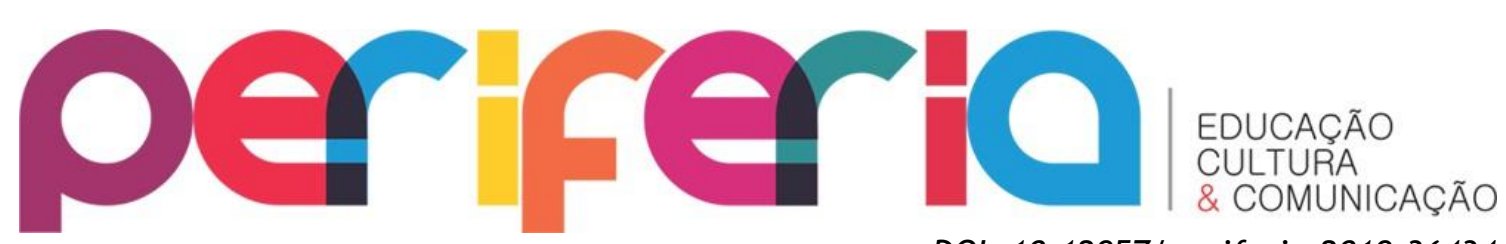

Imagem 15

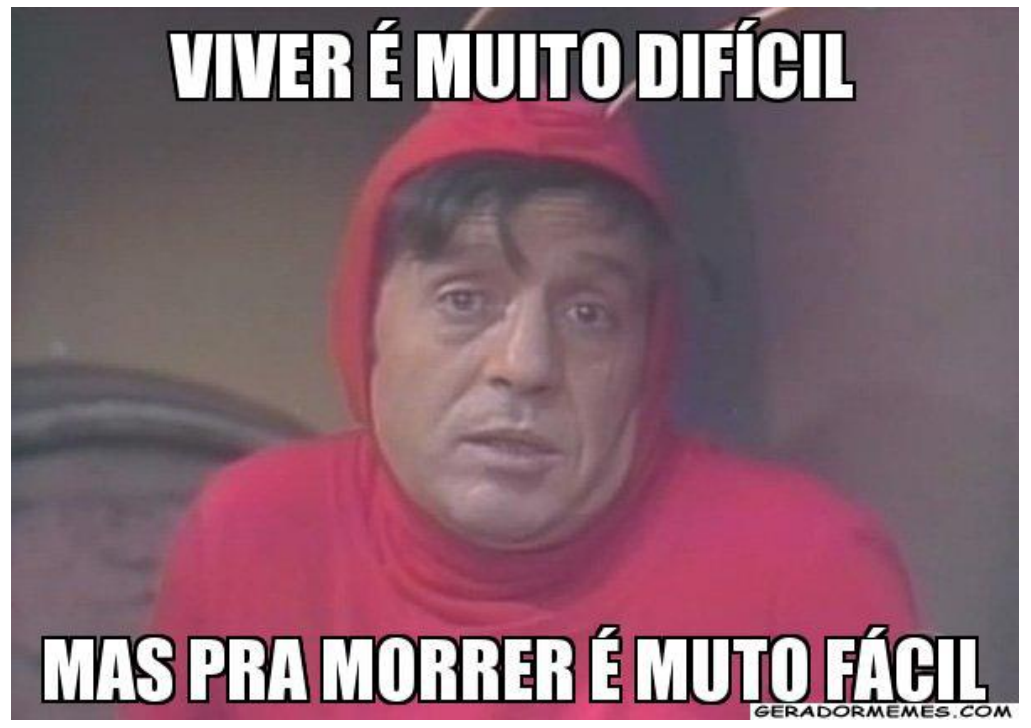

Neste meme (imagem 15), temos o que Charaudeau (1992) define como oposição. Para o autor, a oposição ocorre de forma explícita quando os termos de duas asserções se opõem dois a dois, como no exemplo dado pelo autor: “Enquanto chove em Paris, faz sol em Nice”. Assim, os termos se confrontam dentro do mesmo eixo semântico, como podemos observar no meme da imagem 15: viver/morrer, muito difícil/muito fácil. Neste caso, a conjunção mas foi utilizada para estabelecer a relação lógica de oposição, além do uso de termos antônimos. No entanto, ela também pode ocorrer por meio de justaposição, paráfrase, e outros conectores, como enquanto, ao passo que, entre outras.

No meme da imagem 16, observamos mais uma intertextualidade com letra de música como na imagem 8. Desta vez, com a música "Sinais" do cantor e compositor Djavan, associando a letra da música, adaptada ao meme, à própria imagem do cantor. Este meme é um exemplo do efeito contextual de restrição. 0 efeito tem o sentido de uma objeção de uma asserção em relação à outra, é uma contrajunção. Quando se diz "visualizou a mensagem e não respondeu" nós temos esta restrição, já que o que se espera quando uma pessoa lê uma mensagem é que ela responda. 

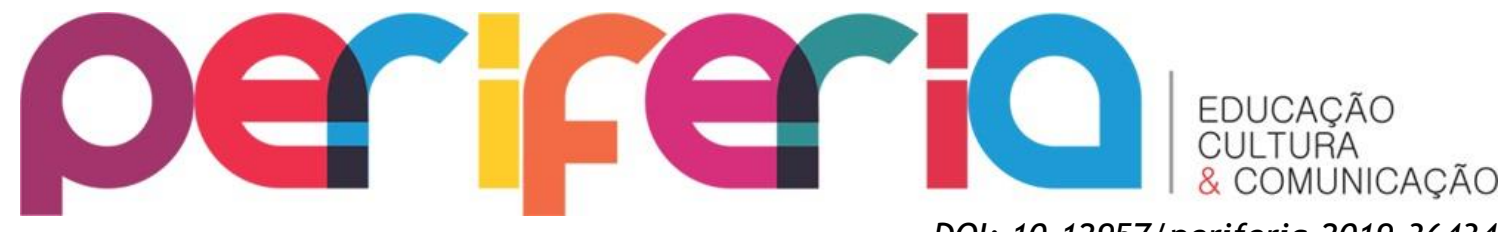

Imagem 16

DOI: $10.12957 /$ periferia.2019.36434

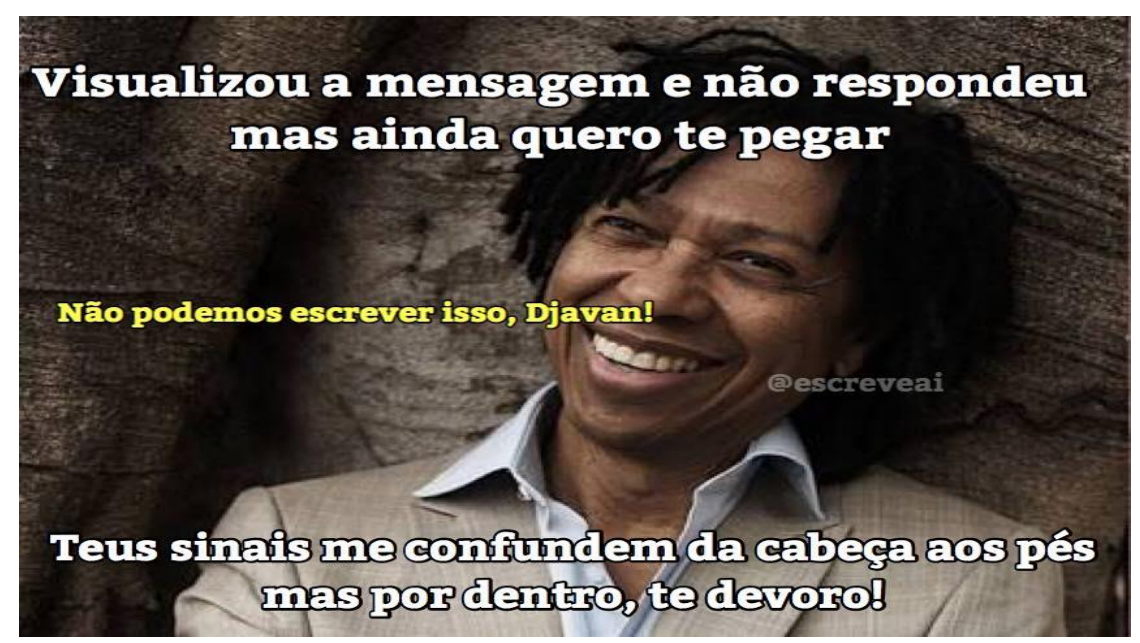

Mais um exemplo dos fatos do discurso propostos por Charaudeau (1992) em sua Gramática da expressão e do sentido é a relação lógico-semântica que indica uma consequência através da conjunção, que, no caso de nosso estudo, é a conjunção "e". Isto pode ser verificado no exemplo que segue (imagem 17).

Nesse caso, é utilizado o conector "e" na ligação das duas asserções, trazendo o sentido de consequência. No meme 17, há o enunciado: "Vote em mim/ e vou dar-vos guerra com a China e a Rússia", ou seja, a consequência do voto das pessoas no sujeito em questão (Hillary Clinton) é haver guerra com a China e a Rússia.

\section{Imagem 17}

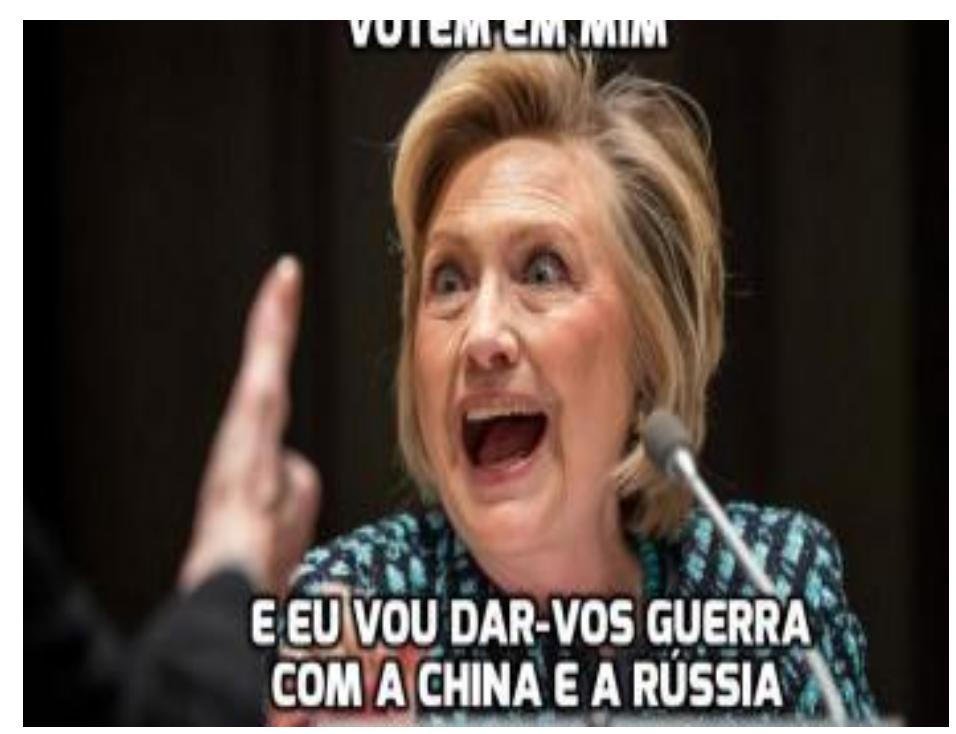




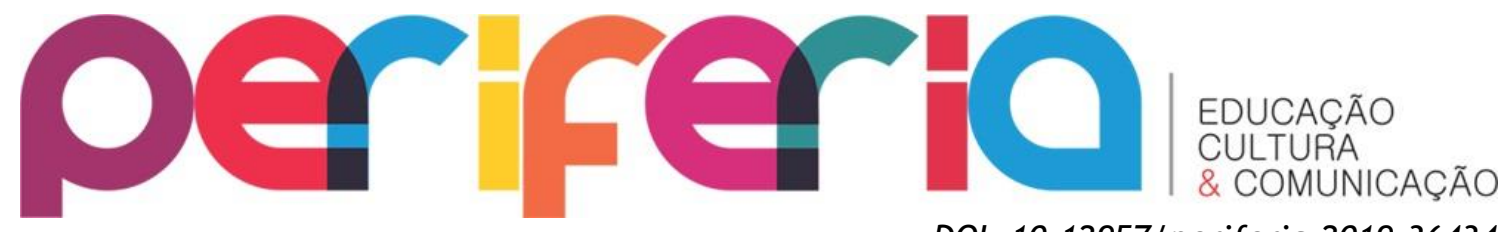

DOI: $10.12957 /$ periferia.2019.36434

0 último exemplo de fatos do discurso é o de aproximação. Observemos a imagem 18 a seguir:

Imagem 18

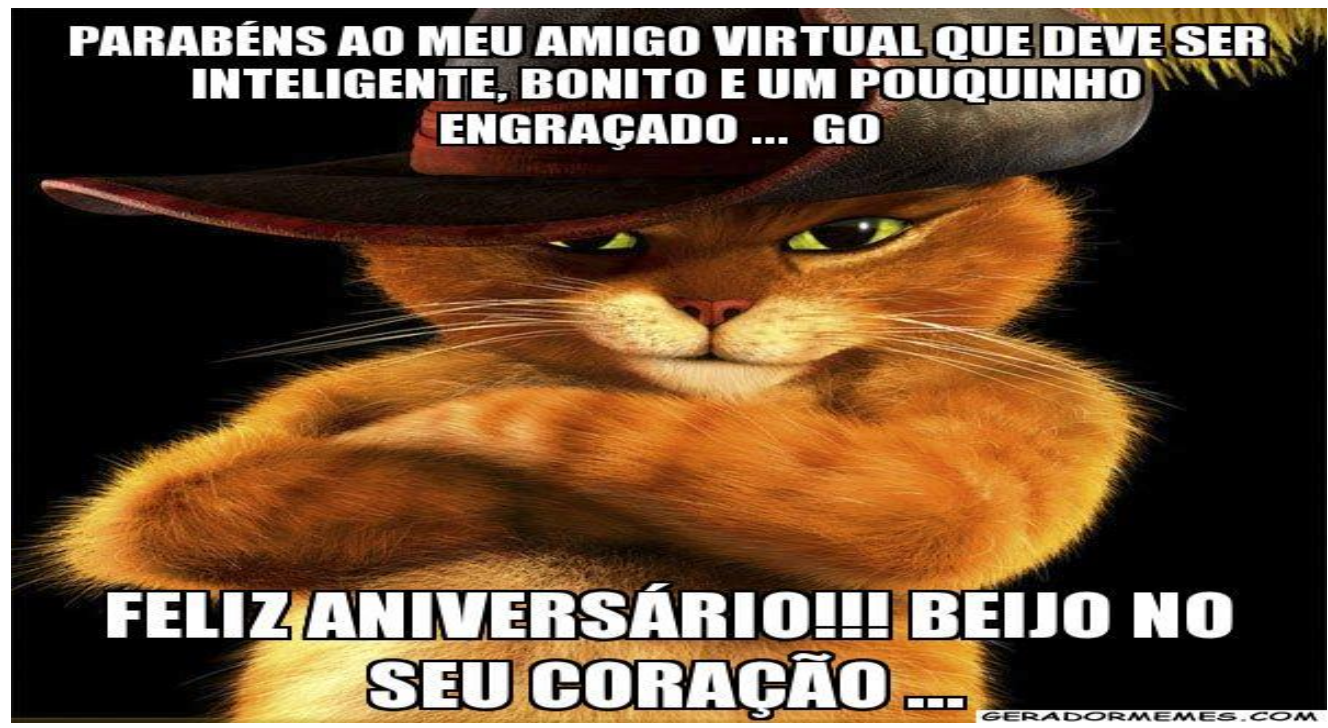

Este efeito de aproximação ocorre, como no exemplo acima, quando uma asserção se liga a outra trazendo um valor, ou algo que não seja exato, estimase uma quantidade e aproxima-se: “Parabéns ao amigo virtual que deve ser inteligente, bonito e um pouquinho engraçado".

Observamos que os primeiros adjetivos dados ao "amigo virtual” não são definidos em quantidade, “inteligente, bonito”, mas, na última característica, afirma-se que precisa ser “um pouquinho engraçado". Não muito, não só engraçado, mas um pouquinho. Podemos dizer que esta definição dada ao adjetivo ‘engraçado’ não pode ser quantificada, determinada, por isso chamada de aproximação.

\section{CONSIDERAÇÕES FINAIS}

Neste trabalho, analisamos as relações lógico-semânticas da conjunção em memes que circulam nas redes sociais. Vimos que o gênero textual meme corresponde a uma viralização de informações que atinge muitas pessoas 


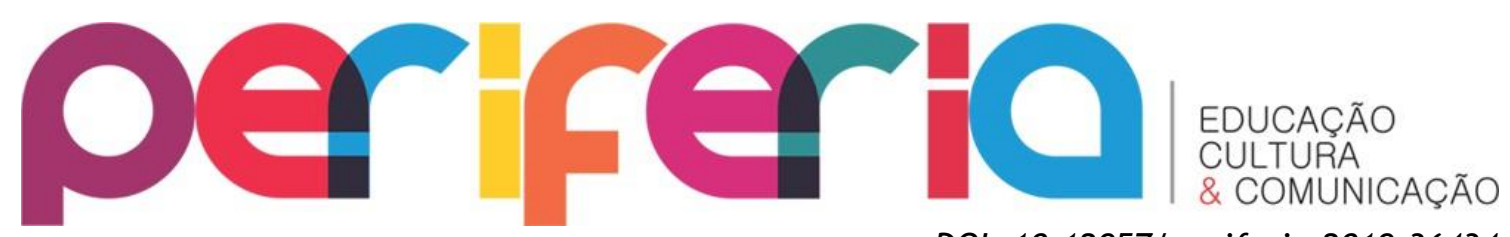

DOI: $10.12957 /$ periferia.2019.36434 rapidamente, trazendo humor, crítica, reflexões sobre variados temas da atualidade.

Foi possível observar a regularidade de pessoas públicas, como jogadores de futebol, artistas e políticos, na construção desses textos. Além disso, há também, em grande medida, conhecimentos compartilhados por um determinado grupo ou cultura, o que é essencial para sua compreensão.

Outro aspecto que gostaríamos de ressaltar é que esse tipo de texto possui uma linguagem, na maioria das vezes, do uso informal da língua, ou seja, uma língua mais próxima do uso real. Este foi um fator importante para esta pesquisa, já que nosso objetivo era trabalhar com a reflexão mais ampla sobre a língua, a partir da Gramática do sentido e da expressão (CHARAUDEAU, 1992).

Observamos, nos diversos exemplos trazidos aqui, que uma conjunção, ou outra classe gramatical, não pode ser descrita e limitada a um único sentido, como tem sido feito pelas gramáticas tradicionais e utilizado pelas escolas de educação básica do Brasil. Isto porque, a partir do uso, podem ocorrer diversos efeitos contextuais para o mesmo elemento linguístico, como vimos nas análises.

Após as análises, podemos afirmar que é preciso considerar, no ensino de Língua Portuguesa em nossas escolas, que apenas decorar relações de conectores e suas relações correspondentes não traz um satisfatório aprendizado da língua, uma vez que não se considera o uso real dos falantes.

Assim, a proposta de Charaudeau nos permite uma perspectiva mais ampla, o que possibilita trabalhar as relações lógicas em seus múltiplos aspectos semânticos. Isso contribui para uma melhor compreensão dos diversos textos que nos cercam, fazendo, desta maneira, com que haja leitores mais eficientes e fluentes de sua própria língua materna.

\section{REFERÊNCIAS}

BARRETO, Krícia Helena. Os memes e as interações sociais na internet: Uma interface entre práticas rituais e estudos de face. 147 folhas. Tese de doutorado, Programa de Pós-graduação em Linguística, Universidade Federal de Juiz de Fora, Faculdade de Letras, Juiz de Fora, 2015. 


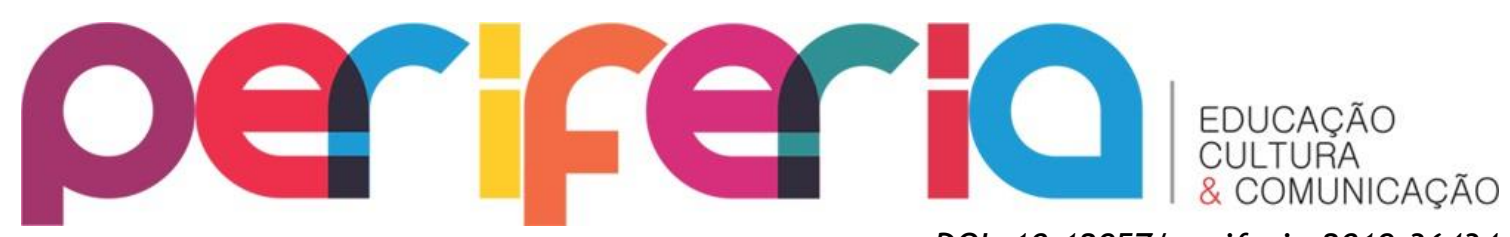

DOI: $10.12957 /$ periferia.2019.36434

CHARAUDEAU, Patrick. Grammaire du sens et de l'expression. Paris:

Hachette, 1992.

CHARAUDEAU, Patrick. Linguagem e Discurso - modos de organização. São

Paulo: Contexto, 2014.

CORREAA-ROSADO, Leonardo Coelho. Teoria Semiolinguística: Alguns pressupostos. Revista Memento, Três Corações, v. 05, n. 2, p. 1-18, julhodezembro de 2014. Disponível em:

http://periodicos.unincor.br/index.php/memento/article/view/1826. Acesso em: 25 de janeiro de 2018.

MACHADO, Ida Lúcia. A AD, a AD no Brasil e a AD do Brasil. In. DE PAULA, L.; STAFUZZA, G. (Org.). Da análise do discurso no Brasil a análise do discurso do Brasil: três épocas histórico-analíticas. Uberlândia/MG: EDUFU, 2010, p. 203230.

MACHADO, Ida Lúcia. Algumas reflexões sobre a teoria Semiolinguística. In: Letras e Letras, Uberlândia, v. 22, n. 2, p. 13-21, jul/dez de 2006.

MONNERAT, Rosane Santos Mauro. Por que ensinar Língua Portuguesa a falantes nativos? In: CÍRCULO FLUMINENSE DE ESTUDOS FILOLÓGICO E LINGUÍSTICOS, 2008, Rio de Janeiro, Cadernos do CNLF, v. XII, n. 4, Ensino de Língua Portuguesa, Rio de Janeiro: UERJ, 2008, p. 121 a 133. Disponível em: http://www.filologia.org.br/xiicnlf/04/volume_04.pdf Acesso em: $10 \mathrm{de}$ janeiro de 2018.

MORAES, Francine; MENDES, Gustavo; LUCARELLI, Talita. Memes na internet: a web 2.0 como espaço fecundo para propagação. In: XXXIV CONGRESSO BRASILEIRO DE CIÊNCIAS DA COMUNICAÇÃO, 2011, Recife, Anais do XXXIV Congresso Brasileiro de Ciências da Comunicação. Pernambuco: Universidade Católica de Pernambuco, 2011, p. 1-15. Disponível em:

http://www.intercom.org.br/papers/nacionais/2011/resumos/R6-2277-1.pdf. Acesso em: 25 de janeiro de 2018.

OLIVEIRA, Helênio Fonseca de; MONNERAT, Rosane Santos Mauro. O emprego de algumas conjunções no texto. In: PAULIUKONIS, M. A. L.; GAVAZZI, S. (Org). Da língua ao discurso: Reflexões para o ensino. Rio de Janeiro: Editora Lucerna, 2005, p. 90-101.

PAULIUKONIS, Maria Aparecida Lino. Texto e Discurso: Desafios no Ensino de Português. In: Revista Letras e Letras, v. 29, n. 2, 2013. Disponível em: http://www.seer.ufu.br/index.php/letraseletras/article/view/25979. Acesso em: 13 de fevereiro de 2018.

SIGNIFICADO DOS MEMES. Disponível em: https://www.significados.com.br/meme/ Acesso em: 07 de novembro de 2017. 


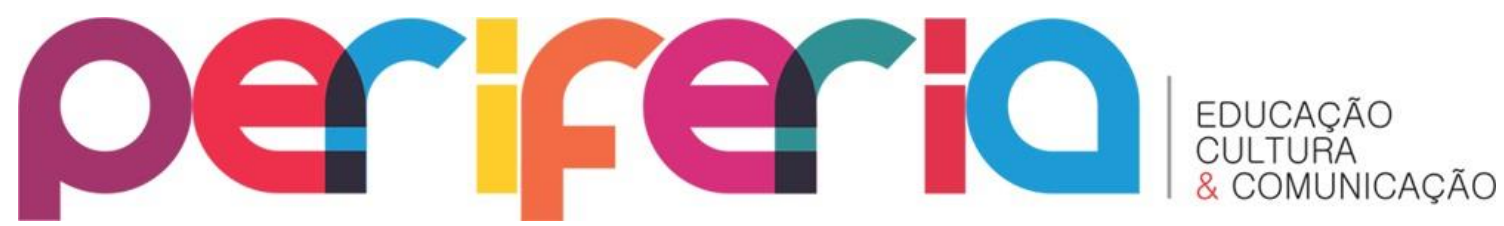

DOI: $10.12957 /$ periferia.2019.36434

SOUZA, Carlos Fabiano de. Memes: formações discursivas que ecoam no ciberespaço. Vértices, Campos dos Goytacazes, v. 15, n. 1, p. 127-148, janeiro a abril de 2013. 